\title{
La persuasió de la lògica i la lògica de la persuasió: les proposicions en vers del Dictat de Ramon (1299) de Ramon Llull
}

\author{
Persuasion of logic and the logic of persuasion : the propositions \\ in verse from Dictat de Ramon (1299) by Ramon Llull
}

\author{
Anna Fernàndez-Clot / Francesc Tous \\ annafzc@gmail.com \\ ftous.prieto@gmail.com
}

Universitat de Barcelona - Centre de Documentació Ramon Llull

\begin{abstract}
Resum: En aquest article s'aborda l'estudi del Dictat de Ramon, una obra en vers que té el propòsit d'aportar arguments per provar els sis articles més destacats de la fe cristiana. Cada una de les sis parts en què es divideix el text conté vint, deu o dotze dístics que condensen en forma de proposició o màxima els arguments que s'addueixen. En el treball s'examina, en primer lloc, les estructures i les formulacions logicosemàntiques d'aquestes proposicions, entre les quals destaquen sobretot les construccions condicionals; en segon lloc, s'estudia la funció de la rima i la versificació, i es descriuen de forma sintètica els recursos estilístics que Llull empra en la redacció dels dístics; finalment, es valora la recepció de què ha estat objecte el text per part de la crítica contemporània. El treball destaca que la tria del vers i del discurs sentenciós s'ha de posar en relació amb el destinatari específic al qual va adreçat el text, el rei Jaume II d'Aragó, i amb la petició amb què Llull clou el poema: la sol licitud d'un permís perquè pugui predicar a les sinagogues i les mesquites dels territoris de la Corona d'Aragó.
\end{abstract}

Paraules clau: Ramon Llull; retòrica; lògica; mètrica i versificació; disputa interreligiosa

\begin{abstract}
In this paper, we deal with the study of the Dictat de Ramon, a work in verse that has the aim to provide arguments proving the most important articles of Christian religion. Each one of the six parts in which the poem is divided contains twenty, ten or twelve couplets that condense the arguments into the form of a proposition or maxim. Firstly, we analyze the semantic and logcial structures of the propositions, among which stand out the conditional clauses; secondly, we examine the function of the rhyme and the versification, and we sum up the stylistic and rhetorical figures used to compose the couplets; finally, we evaluate the reception of the text. One important aim of our study is to emphasize that the choice of verse and maxims is clearly linked with the addresee of the text, the king James II of Aragon, and with the petition that concludes the poem: the request of a permission to preach in the sinagogues and the mosques of the territories of the Kingdom of Aragon.
\end{abstract}

Keywords: Ramon Llull; rhetoric; logic; meter and versification; religious dispute

DATA PRESENTACIÓ: 10/10/2014 ACCEPTACIÓ: 22/11/2014 ·PUBLICACIÓ: 15/20/2014 
Anna Fernàndez-Clot / Francesc Tous. La persuasió de la lògica i la lògica de la persuasió:

les proposicions en vers del Dictat de Ramon (1299) de Ramon Llull

\section{Introducció ${ }^{1}$}

En aquest treball ens proposem d'analitzar els procediments lògics i retòrics que Llull va emprar en el Dictat de Ramon, una obra en vers escrita la tardor de 1299 de camí cap a Barcelona. Llull tot just acabava d'abandonar París. La Vita coaetanea informa en poques paraules que, durant la segona estada en aquesta ciutat (1297-1299), Ramon va llegir públicament la seva Art, va escriure molts llibres i es va entrevistar amb el rei de França, «supplicans ei super quibusdam perutilibus ecclesiae sanctae Dei». Els resultats d'aquestes empreses van ser més aviat exigus i, per aquesta raó, Llull va decidir tornar a Mallorca, «ubi trahens moram, conatus est tam disputationibus quam etiam praedicationibus trahere Saracenos innumeros ibi morantes in uiam salutis», i on va escriure diverses obres en vulgar d'orientació didàctica (Llull 2013: 84). ${ }^{2}$ El Dictat de Ramon (a partir d'ara $D R$ ) inaugura aquest nou període en l'activitat de Llull: l'obra està dedicada a Lluís IX de França ${ }^{3}$ i a Jaume II d'Aragó i, tot apel lant a la utilitat d'aquest «nostre mou» ('manera', 'mode') per disputar contra els infidels i mostrar la veritat de la fe cristiana, Llull acaba adreçant al monarca una petició per poder predicar a les sinagogues i mesquites dels seus territoris. ${ }^{4}$

En consonància amb aquest propòsit pràctic, l'objectiu general que guia la redacció del $D R$ és de signe apologètic: «donar ensenyament» sobre com es poden demostrar els principals articles de la fe. Ho podem llegir al pròleg de l'obra: ${ }^{5}$

1 Volem expressar el nostre agraïment més sincer als nostres mestres, Anthony Bonner, Lola Badia, Albert Soler i Joan
Santanach, que sempre ens han encoratjat en la nostra tasca i han guiat amb mà experta els nostres primers passos
en l'estudi de les obres de Llull. Sense el seu suport, la seva dedicació i la seva inspiració aquest treball no hauria estat
possible. D'altra banda, aquest treball s'inscriu en el marc del projecte FFI 2011-27844-C03-01, «Corpus Digital de
Textos Catalanes Medievales, III: Llull DB, DTCA» de la Universitat de Barcelona, finançat per la Secretaría de Estado
de Investigación, Desarrollo e Innovación del Ministerio de Economía y Competitividad. Al mateix temps s'emmarca
en les activitats del Grup de Recerca Consolidat SGR 2009-1261 de la Generalitat de Catalunya, «Grup de Cultura i
Literatura a la Baixa Edat Mitjana». Anna Fernàndez-Clot és beneficiària d'una ajuda FPU del Ministeri d'Educació
i Cultura (EDU/61/2011: AP2010-0242); Francesc Tous ha rebut un ajut a la recerca de la Fundació Joan Maragall
(curs 2013-2014) i anteriorment havia gaudit d'una ajuda FPI del Ministeri de Ciència i Innovació (BES-2009-015667). 2La Vita coaetanea omet la curta estada de Ramon a Barcelona, on Llull degué passar els darrers mesos de 1299. Les Oracions de Ramon, una obra encarregada per Jaume II i la seva esposa, Blanca d'Anjou, foren escrites en aquesta ciutat.

3 Fernando Domínguez (1996: 50) creu que la dedicatòria a sant Lluís «hay que verla, quizá, bajo la impresión de su, entonces, reciente canonización llevada a cabo por Bonifacio VIII en 1297».

4 Gràcies a un document del 30 d'octubre de 1299 (Hillgarth 2001: 71-72, doc. 35), sabem que la petició de Llull va ser atesa i que va obtenir l'autorització de Jaume II d'Aragó per predicar en els recintes de les comunitats no cristianes.

5 Citem sempre d'acord amb l'edició de Salvador Galmés (Llull 1936: 263-274).

SCRIPTA, Revista internacional de literatura i cultura medieval i moderna, núm. 4 / desembre 2014 / pp. 200 - 220 ISSN: $2340-4841 \cdot$ doi:10.7203/SCRIPTA.4.4493 
Anna Fernàndez-Clot / Francesc Tous. La persuasió de la lògica i la lògica de la persuasió: les proposicions en vers del Dictat de Ramon (1299) de Ramon Llull

\author{
A cells qui dihen que provar \\ hom no pot la fe, ni donar \\ null necessari argument, \\ volem donar ensenyament \\ de .vii. articles principals, \\ los quals, per rahons naturals, \\ provam per nous començaments, \\ qui mostren inconvenients \\ esser en Deu sens unitat, \\ sens trinitat, sens encarnat, \\ sens crear, sens resuscitar. \\ Encara volem demostrar \\ Deus esser de necessitat. \\ Emperò est nostre Dictat \\ requer haver ensenyador, \\ qui mostre la força major \\ qui està per los consequents \\ qui ixen dels antecedents, \\ nous començaments appellats. 10

\author{
Comensem donchs ab la clardats \\ del Sant Spirit gloriós, \\ qui complesca nostres rasós \\ e enlumín hom obstinat, \\ qui no pot veser la claredat \\ sotsposant que no 's pusca far \\ que nostra fe $s$ pusca provar. \\ Provem anans que Deus es, \\ en aprés que sol un Deus es; \\ puys provarem pluralitat \\ qui en Deu mostra trinitat; \\ e que Deu ha volgut mostrar \\ sa bontat volent-se encarnar; \\ e que 1 mon nou es començat; \\ e c'om será resuscitat, \\ a gloria o a turment, \\ per Deu qui es omnipotent. \\ Ara comencem en axí \\ per lausar Deu qui anch no mentí. 40
}

La seva proposta consisteix a oferir un conjunt d'arguments necessaris concentrats en forma de proposicions breus, que han de quedar impreses en la memòria del receptor. Per aconseguir aquest efecte, Llull se serveix d'una estructura versificada que li permet agrupar tots els arguments que demostren un determinat article en una sola unitat formal i temàtica (el capítol) i, a la vegada, mantenir l'autonomia de cada argument com a unitat de sentit (el dístic). L'obra es divideix en sis capítols, que corresponen als sis articles de la fe que Llull es proposa demostrar: l'existència de Déu, la unicitat de Déu, la trinitat, l'encarnació, la creació del món i la resurrecció. ${ }^{6}$ Cada capítol presenta un conjunt de màximes codificades gràcies al motlle formal proporcionat per l'esquema mètric de les noves rimades, això és, els apariats octosíl labs. Cada apariat, doncs, correspon a una màxima o proposició lògica en la qual Llull sintetitza un argument que demostra l'article tractat. El nombre de proposicions per capítol varia entre els quatre primers i els dos darrers, però l'estructura és molt regular i, com ha observat Fernando Domínguez (Llull 1993: 330-331, 334), sembla que segueix un patró numèric. Els quatre primers capítols contenen vint proposicions (és a dir, quaranta versos), el cinquè deu i el darrer dotze. Al final de cada capítol, Llull afegeix un apariat que funciona com a confirmació que l'article en qüestió ha estat demostrat mitjançant les proposicions: «Provat es, donchs, e demostrat / que Deus es de necessitat» (I, v. 81-82) per al primer, o «Mostrat havem per gran raysó / que sia resurreció» (VI, v. 255-256) per al darrer.

6 Malgrat que al vers 7 del pròleg Llull afirma que vol donar ensenyament «de .vii. articles principals», a continuació (v. 11-15) n'enumera només sis. Més endavant, quan enuncia l'estructura del text (v. 29-38), enumera també sis articles, d'acord amb l'ordre dels capítols de l'obra. 
Anna Fernàndez-Clot / Francesc Tous. La persuasió de la lògica i la lògica de la persuasió: les proposicions en vers del Dictat de Ramon (1299) de Ramon Llull

Poc després d'acabar el $D R$, i ja a Barcelona, Llull va redactar un autocomentari de l'obra, el Coment del Dictat, en què exposa d'una manera analítica el sentit dels arguments expressats sintèticament al poema i permet que les proposicions del $D R$ puguin ser enteses sense necessitat d'un «ensenyador» (vg. els v. 16-21 del pròleg del DR). Més tard, el juliol del 1300, a Mallorca, va preparar una versió lliure en llatí d'aquest comentari, el Tractatus compendiosus de articulis fidei catholicae. ${ }^{7}$ Aquestes obres, que han circulat de forma autònoma respecte del $D R,{ }^{8}$ presenten petites variacions pel que fa a l'ordre d'exposició d'algunes proposicions: les màximes 17 i 18 del tercer capítol apareixen invertides i el darrer capítol està format per deu proposicions i no dotze en una part de la tradició del DR i dels comentaris. ${ }^{9}$ Aquest fet demostra el caràcter autònom que tenen les proposicions formalitzades en els apariats respecte de la resta del discurs que forma el capítol, i per això poden funcionar en un ordre diferent o ser omeses i/o afegides. Es tracta d'un tret que particularitza el DR en relació amb altres obres en vers de Llull, i el relaciona amb el discurs propi de les col leccions de proverbis i altres formes aforístiques.

$\mathrm{Al} D \mathrm{R}$ hi ha una confluència original de diversos recursos retòrics i mecanismes lògics que Llull posa al servei dels seus objectius apologètics. La condensació expressiva de la màxima en forma rimada permet fixar de manera eficaç i mnemònica els continguts que Llull vol transmetre, i l'ús d'unes determinades estructures lògiques fa possible l'exemplificació d'un mètode de disputa basat en arguments racionals que siguin més potents per convèncer els adversaris. És evident que la conversió dels no creients, la preocupació més important de Llull, es troba a l’horitzó final del text. Per aquesta

\footnotetext{
7 Aquestes tres obres han estat estudiades per Fernando Domínguez a propòsit de l'edició de les versions llatines dels textos (Domínguez 1991 i 1996, i Llull 1993). Sobre l'operació d'autocomentari del DR, vegeu Badia 2013. L'estratègia comunicativa que engloba el DR, el Coment i el Tractatus ha estat analitzada per qui signa aquestes ratles en un treball, de pròxima publicació, presentat a la secció Formació, organització i transmissió del saber a l'Édat Mitjana $i$ al Renaixement a la Corona d'Aragó del 24è Col loqui germanocatalà celebrat a Bochum el setembre de 2014: «Versos, màximes i arguments necessaris per demostrar els articles de la fe. El Dictat de Ramon (1299) de Ramon Llull i els seus autocomentaris».
}

8 Per la transmissió textual de cada una d'aquestes obres, vegeu les fitxes corresponents a la LlullDB.

9Les proposicions III, 17-18 del DR (en l'ordre que han estat editades per Galmés a ORL XIX i d'acord amb la tradició catalana medieval) apareixen invertides en una part de la tradició del text (ms. 110 de la SAL) i al Coment, tant en la versió catalana (d'acord amb l'edició de Galmés a ORL XIX i amb el text transmès pel ms. 1/103 del Col legi de Sant Isidor de Roma), com en la traducció castellana medieval (Domínguez 1991: 204). Al Tractatus els canvis d'ordre inclouen el grup de proposicions 15, 16, 17 i 18: d'acord amb l'edició de Domínguez (Llull 1993: 487-488), després de la proposició 14 i el seu comentari, segueixen les proposicions en l'ordre 18, 17, 15, 16 segons el referent català. D’altra banda, en el capítol sisè, el testimoni castellà medieval del Coment, els testimonis llatins del DR i els testimonis del Tractatus només transmeten 10 proposicions, com al cinquè capítol de l'obra. D’acord amb l'edició de Galmés, de les últimes quatre proposicions del darrer capítol (VI, 9-12), només la segona (IV, 10) i la quarta (IV, 12) són transmeses en la versió castellana del Coment i al Tractatus: corresponen a les proposicions 9 i 10 d'aquests textos (Domínguez 1991: 219-220; Llull 1993: 503). Domínguez considera que devien ser afegides posteriorment, ja que si es trobessin en l'original haurien estat transmeses en la versió castellana i adaptades al Tractatus (Domínguez 1991: 175 i 1996: 56; Llull 1993: 330-331). 
Anna Fernàndez-Clot / Francesc Tous. La persuasió de la lògica i la lògica de la persuasió: les proposicions en vers del Dictat de Ramon (1299) de Ramon Llull

raó, Fernando Domínguez ha definit el $D R$ com un «guió per a predicadors», un esquema bàsic que ha de mostrar el funcionament d'un mètode adequat per convèncer els infidels que la religió catòlica és la veritable (Domínguez 1996: 59-61). Però cal recordar que Llull va dedicar molts esforços a persuadir els seus contemporanis (intel lectuals, autoritats religioses i autoritats civils) que els dogmes de la fe es podien demostrar mitjançant arguments racionals i que, a més, havia rebut per inspiració divina un mètode infalible basat, precisament, en aquesta classe d'arguments. És de destacar que Llull obri el $D R$ fent referència a aquells que neguen que la fe es pugui provar. En aquest sentit, i tenint en compte que el text està adreçat a Jaume II i conté una petició molt determinada, proposem de llegir el DR com una mena de captatio benevolentiae en què Llull pretén persuadir el monarca que posseeix el mètode adequat per convertir jueus i sarraïns, i ho fa, no només a través d'eines lògiques que exemplifiquen com funciona el mètode, sinó sobretot mitjançant l'ús de formes literàries promogudes i consumides a la cort de Jaume II. ${ }^{10}$

\section{La persuasió de la lògica}

És sabut que una de les constants que guien l'activitat intel lectual de Llull i que justifiquen en bona part la creació de l'Art és la voluntat de fonamentar en raons necessàries la demostració dels articles de la fe, especialment en la disputa amb els membres d'altres confessions religioses, però també en relació amb els pensadors i els apologetes cristians que consideraven que això no era possible. Ja hem vist que el $D R$ és de manera clara una de les moltes realitzacions concretes d'aquest objectiu general. També és sabut que Llull va desenvolupar al llarg de la seva vida mètodes i sistemes lògics que li permetessin superar els límits de la ciència demostrativa aristotèlica. El capítol cinquè de L'Art i la logica de Ramon Llull d'Anthony Bonner descriu de forma detallada els diversos mecanismes que el beat va utilitzar durant l'anomenada fase postartística (Bonner 2012: 211-286).

Tal com Bonner remarca en un altre lloc del llibre (p. 215, n. 8), al DR es fa un ús lleu de les conseqüències, un mètode en voga a finals del s. XIII i que Llull havia assajat especialment als Començaments de filosofia (iniciats a París el 1299 i finalitzats a Mallorca el 1300), ${ }^{11}$ però també al Liber de geometria nova (1299). El lligam entre el DR i aquestes dues obres es pot observar, en primer lloc,

10 Tal com explica Cabré (2011: 354), el rei Jaume, en bona part influït per la política cultural dels seus antecessors, es va interessar per la poesia des de la seva joventut: Jofre de Foixà li va dedicar les Regles de trobar, i Cerverí de Girona el seu Mig vers. Més tard, el rei va escriure «una dansa al legòrica de contingut polític a la qual Arnau de Vilanova va afegir un commentum en llatí». L'interès de Jaume II per la literatura didàctica i sapiencial també és conegut: fou per encàrrec del monarca que el jueu Jafudà Bonsenyor va compilar el seu Llibre de paraules e dits de savis e filòsofs. D'altra banda, és probable que el Llibre de doctrina, que recull materials sapiencials d'origen oriental, fos compilat sota el seu regnat (Cifuentes 2006: 432-433). Arnau de Vilanova va dedicar l'Alphabetum catholicorum a Jaume II per tal que el seu hereu, l'infant Jaume, nascut el 1296, se'n pogués servir (Mensa 2013: 481). Finalment, el 1309, el mateix Ramon Llull envià un llibre de proverbis al rei, també destinat a l'educació dels infants (Hillgarth 2001: 78-79, doc. 40).

11 Llull va redactar el text primer en llatí i a continuació el traduí al català (Pistolesi 2009: 18). Fernando Domínguez s'ha encarregat de l'edició de les dues versions del llibre (Llull 1993: 1-326; Llull 2003).

SCRIPTA, Revista internacional de literatura i cultura medieval i moderna, núm. 4 / desembre 2014 / pp. 200 - 220 ISSN: 2340-4841 · doi:10.7203/SCRIPTA.4.4493 
Anna Fernàndez-Clot / Francesc Tous. La persuasió de la lògica i la lògica de la persuasió: les proposicions en vers del Dictat de Ramon (1299) de Ramon Llull

en la terminologia utilitzada per designar les formes sentencioses. A l'inici del poema Llull anomena dos cops els dístics del $D R$ «nous començaments» (v. 9 i 21). En la rúbrica que encapçala el Coment del dictat també s'utilitza el terme començaments per referir-se als enunciats del DR. Al mateix temps, en el petit pròleg del Coment, les sentències dels dístics també són anomenades proposicions. En canvi, en el Tractatus, en què els enunciats ja han deixat de tenir forma versificada, Llull els denomina maximas necessarias. El terme proposició és el que Llull utilitza més sovint per referir-se a un enunciat de caràcter sentenciós que transmet una veritat i que es pot fer servir per construir arguments. En canvi, màxima i començament, tenen un significat una mica més específic. Encara que a la pràctica puguin funcionar com a sinònims de proposició, la seva generalitat i prioritat els dota d'una força argumentativa i provativa destacable.

En el Liber de geometria i els Començaments de filosofia Llull utilitza llistes de màximes (anomenades començaments -en llatí, principia $)^{12}$ per establir els fonaments teòrics de cada disciplina. A continuació, presenta llistes correlatives de conclusiones o consequentiae en les quals s'extreuen corol laris lògics de les màximes enunciades anteriorment. En general, els començaments d'aquestes obres tenen forma de proposició categòrica: «Negun ents es non ents» (Llull 2003: 7). En canvi, les conseqüències, tenen forma de proposició condicional: «Si negun ens es no ens, inpossible cosa es que no ens sia ens» (p. 13). Aquestes proposicions a vegades es presenten amb la formulació «Com passa X, cové que passi $Y »:$ «Com ens abstractu aja esser en ens concret, cové que enfre esser e essencia aja diferencia» (p. 101). Fernando Domínguez ja va mostrar que l'ús d'aquest procediment lògic està lligat al desenvolupament de la teoria de les conseqüències medievals (Llull 2003: xxviii-xxx). Segons aquest investigador, les conseqüències són un mètode de raonament que tracta de superar les limitacions imposades pel pensament sil logístic. En general, les conseqüències s'expressen mitjançant una proposició condicional formada, de fet, per dues proposicions o dos membres: l'antecedent i el conseqüent. Sembla que els lògics medievals que van desenvolupar aquesta teoria van tendir a admetre només com a veritables conseqüències aquelles en què hi havia una vinculació evident entre l'antecedent i el conseqüent; és a dir, aquelles en què l'antecedent només pot ser veritable si també ho és el seu conseqüent. Això és el que diu, per exemple, Pere Hispà al seu Tractatus, a propòsit de les proposicions condicionals: «Ad veritatem conditionalis exigitur quod antecedens non possit esse verum sine consequenti, ut si homo est, animal est. Unde omnis conditionalis vera est necessaria, et omnis conditionalis falsa est impossibilis» (Pere Hispà 1972: 302). Això és, de fet, el que sembla apuntar Ramon quan al pròleg del DR assegura que cal fixar-se en la «força major / qui està per los consequents / qui ixen dels antecedents» (v. 18-20).

Una gran part de les proposicions del $D R$ són de tipus condicional i, per tant, presenten una forma molt similar a les dels Començaments de filosofia: «Si Deus no es, privació / es fi de generació» (I, 6; v. 51-52), «Si es sol un Deu, possificar / pot en ell infinit estar» (II, 1; v. 83-84). Per tant, en aquest cas, el terme començament té un matís un pèl diferent, atès que no només es refereix a proposicions

12Bonner (2012: 215) informa que Llull no va tornar a utilitzar aquest sistema d'exposició o exploració en cap altra obra. Tampoc enlloc més s'utilitza el terme començament per denominar enunciats breus o formulacions aforístiques.

SCRIPTA, Revista internacional de literatura i cultura medieval i moderna, núm. 4 / desembre 2014 / pp. 200 - 220 ISSN: 2340-4841 · doi:10.7203/SCRIPTA.4.4493 
Anna Fernàndez-Clot / Francesc Tous. La persuasió de la lògica i la lògica de la persuasió: les proposicions en vers del Dictat de Ramon (1299) de Ramon Llull

categòriques que estableixen una relació directa entre dos membres, sinó que també designa proposicions condicionals que contenen conseqüències de tipus negatiu. Com es pot observar, la diferència fonamental és que en el poema Llull aprofita l'estructura lògica proporcionada per les proposicions hipotètiques per demostrar que la negació dels articles de la fe comporta conseqüències impossibles de sostenir i que impedeixen que les proposicions que no s'ajusten a la formulació dels articles de la fe siguin veritables. De fet, Llull no fa altra cosa que aplicar la regla de les conseqüències que Pere Hispà enunciava: si una determinada afirmació genera conseqüències impossibles, s'ha de concloure que és falsa. Aquesta tècnica de demostració dels articles és la base de l'anomenada demonstratio per hypothesim, que Llull sistematitzarà en els darrers anys de la seva vida i que serà una de les noves fórmules emprades per superar els límits demostratius de la sil logística aristotèlica (Bonner 2012: 262-264). Tot i així, Ruiz Simon (1999: 216) assenyala que el procediment de partir d'una hipòtesi i explorar les conseqüències que se'n deriven és present en l'Art des dels seus inicis, i se'l pot considerar, de fet, el principi metodològic més important de l'Art. En l'etapa ternària, aquest procediment deriva de la Regla B, utrum, que pregunta per l'existència d'un determinat particular.

Llull utilitza molt sovint aquest sistema quan vol provar els articles de la fe catòlica. Ho fa, per exemple, en les Flors de l'«Arbre apostolical» de l'Arbre de ciència (1295-96), que es corresponen als catorze articles de la fe. A l'inici de cada argument, Llull extreu conseqüències tant de l'afirmació com de la negació dels articles, amb fórmules molt semblants a les que apareixen al DR: «Si Deus es (...) e si Deus no es (...) Per que 's seguex que (...)»; «Si eren molts deus (...)», «Si son molts deus (...)», «Si 1 mon es eternal (...)». A més, les proposicions condicionals que extreuen conseqüències inviables de la negació d'un determinat principi que es vol provar són omnipresents en l'aforística lul liana. En els primers capítols dels Proverbis de Ramon, una col lecció de proverbis d'abast enciclopèdic que Llull va escriure el 1296, poc després de l'Arbre de ciència, s'utilitza de manera molt sovintejada la proposició condicional. Aquest fet no és gens casual, ja que és just en l'arrencada del recull on el beat aborda els atributs del Déu cristià, entre els quals, evidentment, la trinitat i l'encarnació. En el capítol sobre la trinitat es poden llegir proverbis com el següent: «Si Deus no hagués dedins si metex producció, no la pogra haver defores en les creatures» (Llull 1928: 8). L'estructura condicional també és emprada per mostrar que les virtuts divines contrastarien la seva natura si no es despleguessin de forma ternària: «Ociosa fóra la divina amor si no hagués en sí matexa eternal amant, amable e amar» (p. 9). En els capitols consagrats a les persones divines es repeteix la mateixa estratègia: «Lo Fill no pogra tant amar lo Pare com lo Pare lo pot engenrar, si no fos terça persona» (p. 13). Als Cent noms de Déu (l'obra de la qual pren l'estructura la primera de les tres parts dels Proverbis de Ramon), també es troben habitualment proposicions condicionals relacionades amb articles de la fe: «Si no fos resuscitament, ja no fóra ver jujament del home qui fa falliment» (Llull 1936: 113).

Malgrat que la proposició condicional sigui l'estructura logicosemàntica més visible del Dictat de Ramon, Llull va utilitzar altres motlles sintàctics per aconseguir finalitats similars. De fet, si bé la pràctica totalitat de les proposicions dels dos primers capítols són condicionals, a partir del tercer ni 
Anna Fernàndez-Clot / Francesc Tous. La persuasió de la lògica i la lògica de la persuasió: les proposicions en vers del Dictat de Ramon (1299) de Ramon Llull

tan sols la meitat de les unitats ho són. Concretament en el tercer capítol, de vint dístics, només hi ha dues proposicions condicionals. Alguns d'aquests patrons lògics també tenen la funció d'establir relacions de causa-efecte o de necessitat entre dos elements. Un dels que Llull utilitza habitualment, tant en aquesta obra com en els proverbis i altres formes sentencioses, és la fórmula «Sense X, no Y». En el capítol III n'hi ha dos exemples: «Sens naturant e naturar, / nulla natura pot estar» (III, 4; v. 131-132), «Sens granea e magnifficar, / negú esser pot gran estar» (III, 15; v. 153-154). L'estratègia és exactament la mateixa que en el cas de les proposicions condicionals: demostrar que la no existència d'una determinada realitat (en aquest cas els correlatius: naturant, naturar, magnificar) implica acceptar conseqüències insostenibles (que cap natura pugui ésser, que cap ésser sigui gran). ${ }^{13}$ Les fórmules causals són presents sobretot en el capítol quart: «Car Deus s'es homenificat, / es mays entès e mays amat» (IV, 6; v. 177-178), «Per ço car Deus s'es encarnat, / es mays son judici temprat» (IV, 15; v. 195-196). A diferència de les proposicions que hem analitzat anteriorment, aquest patró presenta una vinculació lògica positiva entre els dos membres de l'enunciat i, per tant, ja no segueix l'estratègia típica de les proposicions condicionals. Tot i així, el resultat és molt semblant, i no costaria gens reformular aquests dístics en forma de proposició condicional: «Si Déu no s’hagués homenificat, no seria ni prou entès ni prou amat».

Un altra estructura molt utilitzada en la redacció de les formes sentencioses i que també és present en el DR és l'oració comparativa, especialment la de superioritat. De fet, la primera proposició del primer capítol conté una comparació d'aquest tipus: «Mays s'an esser e compliment, / que esser e deffalliment» (v. 41-42). Malgrat que en aquest enunciat també hi podríem identificar un antecedent i un conseqüent -entesos de forma laxa-, la proposició funciona com un veritable començament, en el sentit que està enunciada de forma axiomàtica. Estableix el principi bàsic que els contendents d'una hipotètica disputa haurien d'assumir d'entrada i el criteri de veritat que hauria de guiar el debat. Moltes de les conseqüències de les proposicions condicionals posteriors violen de forma explícita aquest principi: «Si Deus no es, car ell no es, / se pert lo be de tot quant es» (I, 14; v. 67-68). La pèrdua, la desaparició del bé present en les coses reals, implicaria clarament que l'ésser concorda més amb el defalliment que no pas amb el compliment. A l'inici del capítol quart també hi ha una estructura comparativa. En aquest cas Llull utilitza el que en anglès s'anomena una fórmula better-than: «Mays val un hom deyficar, / que mil milia mons crear» (v. 167-168). Si bé en aquest cas és evident que, en una disputa amb els jueus o els sarraïns, el contrincant no podria acceptar aquesta premissa, la proposició també estableix com a punt de partida l'afirmació d'una veritat que es defineix mitjançant un contrast de valor. Tot i així, com que el capítol quart conté només cinc condicionals, hi ha moltes més proposicions que estan enunciades de forma categòrica i que, per tant, també tenen la funció de fixar uns determinats principis. La segona diu així: «La fi que en crear es major, / cové amar nostre Senyor» (v. 169-170). La quarta enuncia, amb un llenguatge molt planer, una nova premissa: «La major fi de tota gent, / es Deus esser nostre parent» (v. 173-174).

$13 \mathrm{Vg}$. també les proposicions I, 4 (v. 47-48), IV, 3 (v. 171-172) i V, 2 (v. 211-212). Llull recorre de tant en tant a la fórmula contrària, això és, «Amb X, Y»: «Ab encarnar ha Deus monstrat / l'obra que ha en trinitat» (IV, 14; v. 193-194).

SCRIPTA, Revista internacional de literatura i cultura medieval i moderna, núm. 4 / desembre 2014 / pp. 200 - 220 ISSN: 2340-4841 · doi:10.7203/SCRIPTA.4.4493 
Anna Fernàndez-Clot / Francesc Tous. La persuasió de la lògica i la lògica de la persuasió: les proposicions en vers del Dictat de Ramon (1299) de Ramon Llull

És ben visible que aquestes dues proposicions podrien funcionar com a premissa major i menor d'un sil logisme: convé que Déu desitgi la finalitat més gran de la creació; la finalitat més gran de l'home (i per extensió de la creació) és que Déu sigui el nostre parent, que s'encarni; ergo -podríem concloure nosaltres- convé que Déu s'hagi encarnat.

Així doncs, encara que l'obertura del DR estigui dominada per les proposicions condicionals i la seva estratègia lògica de tipus indirecte (Domínguez 1996: 61), sobretot a partir del tercer capítol -potser quan el lector ja ha interioritzat aquest mètode argumentatiu i ja ha copsat les seves potencialitats persuasives-, Llull amplia el repertori d'estructures logicosemàntiques que li permeten, d'una banda, establir relacions de necessitat i d'interdependència entre dos o més aspectes dels temes tractats d'una manera més flexible, i de l'altra, introduir un discurs de tipus categòric, que afirma, aquest cop de forma més directa, els principis bàsics sobre els quals se sostenen els articles de la fe catòlica. La varietat i la llibertat formal que presenten els quatre darrers capítols de l'obra, des del punt de vista dels patrons lògics utilitzats i de l'alternança d'un discurs de tipus categòric i d'un de tipus condicional, contrasten amb la rigidesa i el caràcter sistemàtic d'una obra com els Començaments de filosofia, i en canvi, emparenten el $D R$ amb altres obres didàctiques que contenen formes sentencioses com les col leccions de proverbis.

\section{La lògica de la persuasió}

Cal entendre aquesta diversitat amb relació a la capacitat de Llull d'assajar tècniques comunicatives diferents per tal de divulgar el seu programa missioner i apologètic i de fer accessibles els continguts de l'Art. És ben sabut que l'ús de formes i recursos retòrics propis de la literatura en la producció lul liana té un caràcter instrumental, d'acord amb els plantejaments sobre literatura que apareixen al capítol 118 del Llibre de contemplació en Déu (1273-1274), "Com hom se pren guarda de ço que fan los joglars». Llull rebutja els objectius, les orientacions i la immoralitat de la literatura consumida a la cort i proposa un canvi de matèria poètica que s'adeqüi a la primera intenció: lloar, estimar i servir Déu. La literatura, doncs, ha de ser una segona intenció o un instrument al servei de la divulgació de la veritat i l'amor a Déu, i l'obra de Llull es presenta com una font per arribar a la primera intenció:

\footnotetext{
[21] Aquells qui volen esser juglars vertaders, en vos a loar e a honrar e a amar e a servir, venguen, Sènyer, e vajen per aquesta Art de Contemplacio: car en ella atrobarán moltes de novelles raons e moltes de belles paraules per les quals vos porán loar e amar e servir: car tota aquesta obra, Sènyer, es comensada e feta per donar laor de vos, e per enamorar en vos e per honrar vos. ${ }^{14}$
}

Per tant, en relació amb la literatura de l'època, Llull proposa una alternativa adequada a la primera intenció i a la seva Art. N'és un bon exemple l'operació retòrica emprada en el Dictat de Ramon, en la qual la forma versificada, els enunciats de caràcter aforístic i l'ús de determinades pautes lògiques s'uneixen per tal de transmetre de manera eficaç un ensenyament doctrinal i metodològic que ha de facilitar la conversió dels infidels per raons necessàries.

14 Llibre de contemplació en Déu, capítol 118, paràgraf 21 (Llull 1906-1914: III, 101). 
Anna Fernàndez-Clot / Francesc Tous. La persuasió de la lògica i la lògica de la persuasió: les proposicions en vers del Dictat de Ramon (1299) de Ramon Llull

En aquesta obra, l'ús del vers juga un paper fonamental, que es pot relacionar -per les seves característiques i objectius- amb altres obres versificades de l'autor. En la tradició medieval, la rima tenia un important valor mnemotècnic: ajudava l'executor a recordar els versos (Canettieri 2003; Santini 2005). Llull se serveix expressament d'aquesta funció didàctica de la rima per difondre continguts tècnics de la lògica (com a la Lògica del Gatzell, 1271-72) o de l'Art, com a les Regles introductòries a la pràctica de l'Art demostrativa (un compendi rimat escrit en alexandrins com a complement per facilitar l'aprenentatge de l'Art demostrativa, 1283-85) o a l'Aplicació de l'Art general (una obra escrita el 1301 en la qual Llull mostra com es poden aplicar els principis generals de l'Art a l'estudi de disciplines concretes). En diversos llocs, ${ }^{15}$ l'autor remarca el valor mnemotècnic de la rima en el procés de difusió i impressió de la seva doctrina i del seu programa en la memòria del receptor $i$, fins i tot, adapta alguns poemes a formes mètriques i melodies conegudes d'acord amb aquests objectius. ${ }^{16}$ Ara bé, d'entre tots els esquemes mètrics i versificatoris a l'abast, Llull es va valdre principalment d'un: els octosíl labs apariats, molt utilitzats en la poesia narrativa i didàctica (vg. Parramon 1992: 227-237).

De les disset obres lul lianes escrites en vers, nou segueixen l'esquema de les noves rimades: la Lògica del Gatzell, Lo pecat d'Adam, les Hores de Nostra Dona, els proverbis rimats de l'Arbre exemplifical (els que són copiats dels Cent noms de Déu, però, són en tercets), el Dictat de Ramon, la Medicina de pecat (excepte alguns capítols de la primera i la segona part que són en tercets), l'Aplicació de l'Art general, els Proverbis de la Retòrica nova i els Proverbis d'ensenyament. Segurament, Llull se serveix sovint d'aquest esquema perquè les tirades d'octosíl labs apariats permeten estructurar les obres amb força llibertat: d'una banda, el text no queda cenyit a un esquema estròfic que limiti l'extensió i la unitat del discurs i, de l'altra, la regularitat del dístic permet cohesionar la sintaxi amb el contingut.

Pel que fa a la primera observació, només cal tenir en compte l'ampli i gradual ventall de possibilitats en què es divideix el discurs en les composicions en noves rimades de Llull: ${ }^{17}$ entre les extenses tirades de Lo pecat d'Adam, que permeten desenvolupar els diversos arguments amb exposició raonada i detallada, d'una banda, i les màximes proverbials del $D R$ que concentren una demostració

15 Lògica del Gatzell (v. 5-10), pròleg dels Cent noms de Déu, Desconhort (v. 817-819), Medicina de pecat (v. 10-11). Al Desconhort de Nostra Dona (v. 377-379) i a l'Aplicació de l'Art general (v. 15-16), sense fer referència explícita a la rima, Llull esmenta la impressió mnemònica dels temes respectius dels poemes com a objectius de composició. Es poden llegir els textos a Llull 1936 i Llull 1938.

16 Per les Hores de Nostra Dona i els Cent noms de Déu Llull proposa que es cantin d'acord amb melodies pròpies de la litúrgia, els himnes i els salms (vg. Sari 2011: 54-56 i Llull 2012: 31-32); el Desconhort de Ramon, en alexandrins, respon a una melodia èpica, el «so de Berart», com també el Desconhort de Nostra Dona (vg. Llull 2012: 101); finalment, el Concili es proposa en forma cantada (v. 1-7) i aprofita el recurs del refrany a l'última secció (v. 694-809) per canalitzar el missatge exhortatiu i propagandístic de Llull en un ambient de cort (Romeu i Figueras a Llull 1958: 17-18, 22, 36-37).

17 Les obres escrites en altres esquemes versificatoris presenten estrofes regulars, siguin monorrims com en les composicions en alexandrins o com els octosíl labs del Cant de Ramon, siguin de metre anisosil làbic i/o rimes diferents com en el Concili o en les poesies del Blaquerna.

SCRIPTA, Revista internacional de literatura i cultura medieval i moderna, núm. 4 / desembre 2014 / pp. 200 - 220 ISSN: 2340-4841 · doi:10.7203/SCRIPTA.4.4493 
Anna Fernàndez-Clot / Francesc Tous. La persuasió de la lògica i la lògica de la persuasió: les proposicions en vers del Dictat de Ramon (1299) de Ramon Llull

en només dos versos, de l'altra, trobem casos intermedis com el de la Lògica del Gatžell, en què, sense necessitat d'una divisió de capítols, el discurs s'ordena clarament per seccions que giren entorn de la definició o explicació d'un principi, i la seva extensió s'adequa a les necessitats expositives de cada argument; o casos com els de les primeres parts de la Medicina de pecat i les Hores de Nostra Dona, en què Llull defineix capítols d’una extensió regular, més aviat breu (vint versos a la primera obra $\mathrm{i}$ dotze a la segona), ${ }^{18}$ però organitza el discurs interior de cada capítol en diverses unitats de sentit o parts expositives. Pel que fa a l'adequació entre la sintaxi i el contingut en l'esquema mètric, és interessant observar com, al discurs interior d'una secció o capítol dels poemes, per tal de remarcar algunes definicions o relacions entre conceptes, Llull emmarca la sintaxi d'una unitat de sentit en l'estructura del vers o del dístic. Vegem, a tall d'exemple, la segona i la tercera estrofa de la Lògica del Gatzell, en què els apariats de cada secció formen unitats sintacticosemàntiques que permeten enumerar i definir conceptes:

Ech vos los .v. universals, lurs noms sabiats que es aytals: genus, sots sí specia, aprés es diferencia; proprietat e accident són quart e cinquèn exament. Dos són los generals menors qui termenen dintra ls majors: substancia es lo sobirà, animal mortal pus jussà, e 1 mig són cors e animal.

II

De les species, atretals, les dues són estremitats, sí com cors e home nomnat; les altres dues són al mig, sensible e animal dit. ${ }^{19}$

Aquesta estratègia didàctica sembla que està relacionada amb el caràcter sentenciós del discurs que Llull pretén remarcar: és força sistemàtica en una obra didàctica de versos llargs i monorrims com les Regles introductòries i només és utilitzada a les Hores de Nostra Dona o a la Medicina de pecat per definir premisses o símils a partir dels quals s'estructura el discurs d'un capítol. D'altra banda, i com hem vist més amunt, en el DR l'aprofitament de l'apariat de les noves rimades per a la

18 Per l'extensió dels capítols de la Medicina de pecat i la variació entre apariats octosíl labs i tercets de metre diferent en els capítols de les dues primeres parts de l’obra, vegeu Fernàndez Clot (2012: 39-43).

19Llull 1936: 4, v. 13-28. Fixem-nos que l'últim vers de la primera secció forma apariat amb el primer vers de la segona. Com succeeix en la narrativa en vers d'àmbit occitanocatalà, i a diferència del que ocorre a l'interior del discurs d'una secció, és habitual que es parteixin els apariats en els canvis de secció, de manera que el discurs pugui ser reprès fàcilment per la funció mnemotècnica de la rima. 
Anna Fernàndez-Clot / Francesc Tous. La persuasió de la lògica i la lògica de la persuasió: les proposicions en vers del Dictat de Ramon (1299) de Ramon Llull

formalització d'una proposició lògica de tipus demostratiu determina la construcció d'un discurs format per unitats de sentit de caràcter breu amb una estructura sintàctica molt marcada, que s'ajusta a l'estructura mètrica binària. Aquesta divisió del discurs a partir de l'esquema de l'apariat permet reforçar el caràcter binari (antecedent-conseqüent) de l'estructura logicosemàntica de les màximes i permet que, a diferència de les unitats de sentit formades pels versos d'altres obres (que són necessàries per cohesionar el conjunt del discurs d'una secció o capítol), les proposicions del $D R$ puguin funcionar autònomament. Això ens permet relacionar el $D R$ amb les col leccions de proverbis que Llull va escriure.

De fet, el DR forma part d'una família textual, censada recentment (Tous 2011: 80-87), que inclou les col leccions de proverbis i altres obres —o seccions - que també estan construïdes a partir de l'acumulació d'enunciats breus amb autonomia semàntica. En aquest grup es poden incloure textos tan diferents entre si com el Liber propositionum secundum Artem demonstrativam compilatus (1283-1287), els Cent noms de Déu (1292), les Flors d'amor i d'intel ligència (1294) o els ja mencionats Començaments de filosofia (1299-1300). El vincle que els uneix és la fragmentació del discurs en unitats sentencioses independents. La majoria de les obres que conté aquest corpus van ser escrites durant l'etapa ternària de l'Art, atès que els fonaments de l'Art d'aquest període afavoreixen la proliferació d'aquestes formes (vg. Tous 2011: 81-82 i Bonner 2012: 307-309). A l'interior d'aquest grup, el DR té un vincle molt estret amb les col leccions de proverbis rimades, els Proverbis de la Retòrica nova i els Proverbis d'ensenyament, ja que, com hem vist, estan redactades exactament amb el mateix metre. ${ }^{20}$ Malgrat que els objectius i l'orientació d'aquestes obres siguin força diferents als del $D R$, i que totes dues col leccions no disposin de cap tipus d'estructuració dels continguts, Llull recorre de nou al discurs fragmentari construït a partir d'unitats brevíssimes de sentit complet codificades gràcies al motlle dels apariats octosíl labs. Cal destacar, a més, que en els Proverbis d'ensenyament Ramon reaprofita dos dístics del DR. Es pot comprovar que, a excepció del segon vers del prov. 105, la resta dels dos apariats són una represa literal del text del $D R$ :

$\begin{array}{ll}\text { Proverbis d'ensenyament } & \text { Dictat de Ramon } \\ \begin{array}{l}\text { A infinit tany infinir, } \\ \text { mes que a finit lo finir. (prov. 105) }\end{array} & \begin{array}{l}\text { A infinit tany infinir, } \\ \text { mays que crear ni res finir. (III, 10, v. 143-144) }\end{array} \\ \begin{array}{ll}\text { Si finit finir han semblan, } \\ \text { mes infinit infinir l'an. (prov. 106) }\end{array} & \begin{array}{l}\text { Si finit finir han semblant, } \\ \text { mays infinit infinir l'an. (III, 5; v. 133-134) }\end{array}\end{array}$

20 La Retòrica nova, i en conseqüència els proverbis que conté la segona part del tractat, fou escrita el 1301. En canvi, la redacció dels Proverbis d'ensenyament és molt menys segura, si bé a partir de Platzeck (1962-1964: II, *54) hom ha tendit a acceptar que són de 1309. Aquesta datació es basa en la identificació dels Proverbis d'ensenyament amb el recull que Llull envià a Jaume II aquest any (Hillgarth 2001: 78-79, doc. 40), però convé subratllar que la descripció que en dóna Ramon a la lletra no coincideix gaire amb els trets de la col lecció conservada.

$21 \mathrm{El}$ text d'aquests dos proverbis prové de l'edició que Francesc Tous està preparant per a la seva tesi doctoral. Les antigues edicions de Morel-Fatio (1882: 198) i Salvador Galmés (Llull 1928: 382) van reproduir la lliçó deturpada del manuscrit D 465 Inf. de la Biblioteca Ambrosiana de Milà, un dels dos còdexs del s. xvi, provinent de la biblioteca de l'humanista italià Gian Vincenzo Pinelli (1535-1601), que han transmès els Proverbis d'ensenyament. Gràcies a la comparació del text conservat del recull amb el de-l DR s'ha pogut reconstruir la que segurament degué ser la lliçó original d'aquests dos proverbis.

SCRIPTA, Revista internacional de literatura i cultura medieval i moderna, núm. 4 / desembre 2014 / pp. 200 - 220 ISSN: 2340-4841 · doi:10.7203/SCRIPTA.4.4493 
Anna Fernàndez-Clot / Francesc Tous. La persuasió de la lògica i la lògica de la persuasió: les proposicions en vers del Dictat de Ramon (1299) de Ramon Llull

Com va observar Domínguez (Llull 1993: 334) és remarcable «la habilidad que muestra Llull en metrificar una materia tan árida des de un punto de vista literario» i l'esforç que fa l'autor per «trasponer los más árduos temas en un lenguaje científico, filosófico y teológico, aún a costa de latinismos y de morfología de clara procedencia escolástica». Cal notar, però, que el llenguatge del DR és molt menys tècnic que el que Llull empra en obres com la Logica del Gatzell o les Regles introductòries, que són pensades com a complement per a l'aprenentatge de la lògica o de l'Art; en canvi, més enllà de l'ús de connectors que tenen la funció de mostrar la relació lògica de les proposicions, el llenguatge filosòfic i teològic del DR és força semblant al que trobem a la Medicina de pecat $\mathrm{i}$ a les Hores de Nostra Dona: conceptes com els principis de la Figura A i alguns dels seus correlatius permeten construir el camp semàntic que ha de permetre demostrar un article de la fe o explicar el paper d'un vici o d'una virtut, d'un sagrament o d'una potència humana en unitats breus de sentit. Ara bé, com més breu el discurs, menys espai per desenvolupar l'explicació i, per tant, més dificultat perquè el lector n'entengui el sentit; per això, les màximes del DR necessiten un «ensenyador» (v. 17) o un comentari que expliqui les relacions i les significacions dels principis implicats en cada proposició.

No obstant això, és possible detectar alguns recursos estilístics emprats per Llull en la construcció dels dístics del $D R$ que posen de manifest l’interès de l'autor per facilitar la comprensió i la memorització de les màximes. Llull explota les possibilitats semanticosintàctiques de les relacions lògiques amb un llenguatge accessible; en alguns casos fa ús de la referencialitat (d'espai: «dessús e dejús», v. 90; «deffors», v. 98; «dins sì / «deffores si», v. 169-160; «en altre mon», v. 242; «en est mon», v. 244; o de persona: «mi e vos» / «nos», v. 106-107) i, en general, procura substituir alguns conceptes propis de l'Art i de la filosofia per un llenguatge al lusiu, a partir de termes quotidians o de ressò poètic. Només cal comparar els versos catalans amb la transposició llatina de les màximes al Tractatus compendiosus de articulis fidei catholicae, en les quals Llull utilitza un llenguatge més tècnic i una formalització més especificativa: ${ }^{22}$

\begin{tabular}{|c|c|c|}
\hline $\mathrm{I}, 5$ & $\begin{array}{l}\text { Si Deus no es, no està fi } \\
\text { en meyt dia, vespre e maytí. (v. 49-50) }\end{array}$ & $\begin{array}{l}\text { Si Deus non est, finis perfectionis in nullo tempore } \\
\text { consistit. }\end{array}$ \\
\hline $\mathrm{I}, 16$ & $\begin{array}{l}\text { Si Deus no es, mays val sentir } \\
\text { que rasó, mèrit, ni desir. (v. } 71-72 \text { ) }\end{array}$ & $\begin{array}{l}\text { Si Deus non est, plus habet de esse et perfectione } \\
\text { potentia sensitiua quam intellectiua. }\end{array}$ \\
\hline $\mathrm{I}, 18$ & $\begin{array}{l}\text { Si Deus no es, e qui ha mès } \\
\text { tant bell orde en ço que es? (v. 75-76) }\end{array}$ & $\begin{array}{l}\text { Si Deus non est, quaeritur: Quid est illud ens aut quae } \\
\text { sunt illa entia, quae ita bene, ita pulchre et ita perfecte } \\
\text { naturaliter mundum ordinauerunt? }\end{array}$ \\
\hline II, 8 & $\begin{array}{l}\text { Si són dos deus, cascú ha mon } \\
\text { que fa buyt deffors en redon. (v. 97-98) }\end{array}$ & $\begin{array}{l}\text { Si sunt duo dii, quilibet per se habet unum mundum, et } \\
\text { extra quemlibet mundum est uacuum. }\end{array}$ \\
\hline III, 12 & $\begin{array}{l}\text { Si són molts deus, e mi e vos } \\
\text { n’amam menys lo Deus qui es de nos. } \\
\text { (v. 105-106) }\end{array}$ & $\begin{array}{l}\text { Si sunt plures dii, nos, qui sumus unius Dei, non tenemus } \\
\text { ipsum tantum diligere, sicut si esset unus solus tantum. }\end{array}$ \\
\hline II, 17 & $\begin{array}{l}\text { Si són molts deus, no es .j. fi, } \\
\text { e tot quant es, es pelagrí. (v. 115-116) }\end{array}$ & $\begin{array}{l}\text { Si sunt plures dii, non est unus finis generalis et quicquid } \\
\text { est, est a casu et fortuna. }\end{array}$ \\
\hline $1 \mathrm{~T}, 5$ & $\begin{array}{l}\text { En fi on Deus mays no pot dar, } \\
\text { han ses dignitats repausar. (v. } 175-176 \text { ) }\end{array}$ & $\begin{array}{l}\text { In illo fine, in quo Deus magis dare non potest neque } \\
\text { addere de bonitate, magnitudine, duratione, potestate, } \\
\text { etc., quiescunt suae dignitates. }\end{array}$ \\
\hline
\end{tabular}

22Citem les màximes del Tractatus, a la columna dreta de la taula, d'acord amb l'edició de Domínguez (Llull 1993: 465-504). 
Anna Fernàndez-Clot / Francesc Tous. La persuasió de la lògica i la lògica de la persuasió: les proposicions en vers del Dictat de Ramon (1299) de Ramon Llull

El llenguatge al lusiu dels dístics del $D R$, però, no pren la dimensió d'alguns proverbis de Llull, com els de l'Arbre exemplifical, i d'alguns capítols d'obres en vers com la Medicina de pecat, les Hores de Nostra Dona o Lo concili, en què el discurs admonitori o doctrinal es construeix a partir de símils o personificacions de conceptes abstractes. El patró mètric de les màximes del $D R$ no ho permet. En canvi, sí que permet desenvolupar un interessant joc semàntic i sintàctic fonamentat en estructures binàries. Un joc que està íntimament relacionat amb les diferents estructures logicosemàntiques que Llull utilitza per construir les demostracions en màximes rimades. Als dos primers capítols, el joc sintàctic queda força limitat per la preeminència de l'estructura hipotètica, que obliga a mantenir invariable la meitat del primer vers de l'apariat. Sovint les oracions principals d'aquestes estructures es formen a partir de comparacions o de negacions $i$, en tres ocasions, a partir de preguntes retòriques (I, 18; I, 19; II, 20). Llull tendeix a col locar el verb a l'interior de vers i treu rendiment de recursos semàntics com l'oposició entre conceptes, sobretot en posició de rima: «compliment» / «defalliment» (I, 1; v. 41-42), «infinit» / «finit» (I, 2; v. 43-44), «privació» / «generació» (I, 6; v. 51-52), «no es» / «es» (I, 14; 67-68). Però també a l'interior de vers: «no és tant de be com de mal» (I, 4; v. 48), «fals pensar» / «ver essen» (I, 11; v. 61-62), «dessús e dejús» (II, 4; v. 90).

També trobem jocs d'oposició als altres capítols del poema, però cal tenir en compte que en aquests casos les estructures logicosemàntiques es diversifiquen i Llull utilitza més recursos, entre els quals destaquen les figures de repetició i les figures etimològiques. Les primeres poden ser paral lelismes entre membres dels dos versos de l'apariat; siguin oracions completes: «Si a unitat no tany unir, / ni a voluntat tany desir» (III, 3; v. 129-130), «Mays es cell qui es e qui fa, / que cell qui es e res no fa» (III, 11; v. 145-146); siguin parts d'oracions diferents: «negú ens es bo» / «e tot ens es mal» (III, 17; v. 157-158) o «esser causat» / «esser lausat» (V, 7; v. 221-222). Però també es poden donar dins d'un mateix vers, generalment per coordinació: «es mays entès e mays amat» (IV, 6; v. 178), «Per natura e per crear» (IV, 8; v. 181), "Cell qui crea e qui manté, / mays fa que cell qui sosté» (V, 5; v. 217-218). La figura etimològica apareix amb l'ús dels correlatius de les dignitats divines, cosa que permet desplegar un raonament amb conceptes propis de l'Art lul liana, però sense assolir mai la complexitat que la teoria presenta en altres obres: «Sens naturant e naturar, / nulla natura pot estar» (III, 4; v. 131-132), «Poder no poria eternar / sens infinit possificar» (V, 2; v. 211-212). Val la pena remarcar, també, que en aquests capítols III-VI del DR Llull tendeix a col locar les formes verbals (sobretot infinitius i participis) a final de vers, cosa que es pot relacionar amb l'ús d'estructures logicosemàntiques que imposen una sintaxi més lliure que les hipotètiques i que connecta amb la tendència observada en Llull pel que fa a l'ús de la rima (Ruffini 1966-1967; Sari 2007-2008: 244256; Sari 2012: 381-385; Llull 2012: 102-106).

Aquesta breu síntesi dels recursos retòrics utilitzats en la composició de les màximes versificades del $D R$ posa de manifest que hi ha una construcció conscient d'un discurs persuasiu, amb el qual Llull té l'objectiu d'aconseguir uns determinats efectes sobre el públic potencial del text. La formulació breu dels arguments en sentències o màximes rimades, aprofitant especialment el paral lelisme i altres figures de repetició, genera unes unitats més fàcilment memoritzables per part 
Anna Fernàndez-Clot / Francesc Tous. La persuasió de la lògica i la lògica de la persuasió:

les proposicions en vers del Dictat de Ramon (1299) de Ramon Llull

del receptor, mentre que l'ús d'un llenguatge planer i adaptat al nivell formatiu del públic n'assegura la bona recepció. Tot i així, cal remarcar que l'obscuritat pròpia de les formes breus, que s'ha de superar amb un «ensenyadon» que mostri el sentit dels dístics, també pot funcionar com un estímul intel lectual per al lector, molt del gust d'un autor convençut de la intel ligibilitat de la realitat i de Déu com Ramon Llull.

\section{Difusió i recepció del $D R$ : el text i el seu context}

El DR s'ha conservat en nou manuscrits. Tres d'aquests còdexs transmeten el text de forma fragmentària i només quatre són medievals (s. XIV-XV). N'hi ha tres dels s. XVI-XVII i dos del XVIII. ${ }^{23}$ En bona part d'aquests volums, el $D R$ ha estat copiat al costat d'altres obres en vers del beat. Alguns d'aquests manuscrits es poden considerar veritables cançoners lul lians, especialment el ms. 2017 de la Biblioteca de Catalunya (s. XIv) i el ms. 110 de la Societat Arqueològica Lul liana (s. XVIxVII). Altres manuscrits, com el Vat. lat. 9344 de la Biblioteca Apostòlica Vaticana (s. xv), l'1/71 de la Biblioteca de Sant Isidor de Roma (s. xv) i el 10591 de la Bayerische Staatsbibliothek de Munic, contenen seccions d'obres en vers (Desconhort, Cant de Ramon, Dictat de Ramon, Lo concili) al costat d'altres textos vernacles (Mil proverbis, Llibre de consolació d'ermità, Llibre de Déu, etc.) i de textos llatins de caire apologètic. El fet que el $D R$ s'hagi transmès sempre al costat d'altres obres en vers lul lianes ens obliga a plantejar-nos el seu lloc en el corpus de textos en vers que Llull va escriure. Aquest corpus està format per disset obres:

1. Lògica del Gatzell (1271-1272)

2. A vós, dona verge Maria, dins el Blaquerna (cap. 76) (1276-1283)

3. Sényer ver Déus, rei gloriós, dins el Blaquerna (cap. 115) (1276-1283)

4. Regles introductòries a la pràctica de l'Art demostrativa (1283-1285)

5. Hores de Nostra Dona (1290-1293)

6. Cent noms de Déu (1292 ?)

7. Desconbort de Nostra Dona (1294 ?)

8. Lo pecat d'Adam (1294 ?)

9. Desconhort (1295)

10. Arbre exemplifical. Parts rimades (1295-1296)

11. Dictat de Ramon (1299)

12. Cant de Ramon (1300)

13. Medicina de pecat (juliol de 1300)

14. Aplicació de l'Art general (març de 1301)

15. Proverbis de la Retòrica nova (1301)

16. Proverbis d'ensenyament (1309 ?)

17. Lo concili (octubre de 1311)

23 També s'ha conservat una traducció llatina del s. XviII, transmesa en dos manuscrits d'aquest segle custodiats a la Biblioteca Vivot de Palma, i que és obra del pare Antoni Pasqual. Vegeu la LlullDB.

SCRIPTA, Revista internacional de literatura i cultura medieval i moderna, núm. 4 / desembre 2014 / pp. 200 - 220 ISSN: 2340-4841 · doi:10.7203/SCRIPTA.4.4493 
Anna Fernàndez-Clot / Francesc Tous. La persuasió de la lògica i la lògica de la persuasió: les proposicions en vers del Dictat de Ramon (1299) de Ramon Llull

Es tracta d'un corpus format per textos de naturalesa molt diversa, que la crítica ha procurat descriure com a conjunt a partir de classificacions binàries fonamentades en la forma mètrica dels textos (noves rimades $\mathrm{i}$ altres metres), en el valor estètic (poesies i obres rimades) o, més recentment, en les característiques estructurals i contextuals (obres artístiques i obres de circumstància). ${ }^{24}$

La consideració que ha rebut el Dictat de Ramon en les descripcions i els inventaris de les obres en vers de Ramon Llull ha estat marginal. Cal tenir en compte que, en general, aquestes classificacions es fonamenten en un criteri estètic que separa les obres amb valor poètic («poesia») i les obres sense valor poètic («obres rimades» o «obres didàctiques expositives»). La Lògica del Gatæeell, Lo pecat d'Adam, les Regles introductòries, el Dictat de Ramon, l'Aplicació de l'Art general i els proverbis rimats no són tinguts en compte ni en les edicions divulgatives ni en les descripcions de les obres en vers de Llull. ${ }^{25}$ Partint d'aquesta distinció, doncs, la valoració de l'obra versificada de Llull s'estableix només a partir dels textos següents: els fragments de les obres filosòfiques o teològiques en què l'autor expressa l'amor de Déu i de la Verge (Hores de Nostra Dona, Cent noms de Déu i Medicina de pecat), els fragments de to popular de Lo concili, les poesies del Blaquerna i el Desconhort de Nostra Dona i, finalment, el Cant de Ramon i el Desconhort, que es consideren les obres més ben construïdes des del punt de vista de l'expressió del jo. Per tal de superar aquesta classificació basada en criteris estètics, Simone Sari (2011-2012: 105-120) va proposar una nova divisió temàtica, en la qual pretén tenir en compte les característiques de composició i la naturalesa formal i temàtica dels textos. Estableix dos grans grups de poesies (p. 108-109). D’una banda, les obres artístiques, «pensades per divulgar les Arts de Ramon»: Lògica del Gatzell, Regles introductòries a la pràctica de l'Art demostrativa, Hores de Nostra Dona, Cents noms de Déu, proverbis de l'Arbre exemplifical, Dictat de Ramon, Medicina de pecat, Aplicació de l'Art general, Proverbis de la Retòrica Nova, Proverbis d'ensenyament. De l'altra, les obres de circumstància, «que obeeixen a un pretext exterior a l'Art», és a dir, «que van ser compostes a causa d'una motivació exterior a l'Art»: poesies del Blaquerna, Lo pecat d'Adam, Desconhort de Nostra Dona, Desconhort, Cant de Ramon, Lo concili.

És cert que el $D R$ és una obra didàctica de caràcter expositiu escrita en el metre preferit per Llull per aquest tipus de textos, les noves rimades. I també és cert que, d'acord amb la classificació de Sari, és una obra pensada per divulgar l'Art de Ramon; ara bé, de la mateixa manera que el Pecat d'Adam tant és una obra de circumstància «feta per contestar dues preguntes del rei» com una obra artística -ja que «és a través de l'Art que Llull construeix la seva resposta» (Sari 2011-2012: 108)-, ja hem vist que el $D R$ també és una obra de circumstància, motivada per una finalitat

24 Vegeu les introduccions de les edicions d'obres en vers de Llull (Llull 1936: vii-xxi; Llull 1958: 13-41 [1988: 9-23]) i Sari (2011-2012).

25 Cal precisar, tanmateix, que Romeu i Figueras (Llull 1958: 25 [1988: 15, 20]) remarca el valor literari d'alguns proverbis rimats de l'Arbre de ciència, i que de fet, és el primer a afegir aquests proverbis al catàleg d'obres en vers i a oferir-ne una selecció a la seva edició de les Poesies de Ramon Llull (1958: 89-94 [1988: 69-72]). 
Anna Fernàndez-Clot / Francesc Tous. La persuasió de la lògica i la lògica de la persuasió: les proposicions en vers del Dictat de Ramon (1299) de Ramon Llull

concreta $\mathrm{i}$ amb un destinatari clar. ${ }^{26} \mathrm{Cal}$ tenir en compte, doncs, que les classificacions poden caracteritzar un conjunt d'obres, però mai poden donar compte de la singularitat d'un text. Amb l'anàlisi de la tradició manuscrita antiga, per exemple, hom pot copsar que òbviament no existeix ni una divisió neta entre obres amb valor estètic i obres de factura didàctica, ni cap distinció entre obres de circumstància o obres artístiques. ${ }^{27}$ De fet, el $D R$ mostra una tendència destacable a aparèixer al costat del Cant de Ramon, del Desconhort i de Lo concili, fenomen que evidencia que els lectors dels s. XV-XVII percebien una lògica continuïtat entre aquests quatre textos.

Al llarg d'aquest article hem desgranat alguns dels fenòmens que expliquen que el text hagi circulat per certes vies de transmissió. L'anàlisi dels elements que constitueixen el que hem anomenat «la persuasió de la lògica» i «la lògica de la persuasió» ens han permès comprendre com Llull utilitza i combina diversos mecanismes i recursos per adaptar de forma específica els seus objectius missioners i apologètics a un destinatari i un públic concret. En el cas del $D R$, és important remarcar que la selecció de les formes d'expressió sembla estar condicionada pel bagatge cultural i els gustos literaris del dedicatari de l'obra, el rei Jaume II, i el seu entorn sociocultural (vg. més amunt, la nota 9). D’altra banda, la tria del discurs fragmentat en unitats breus de sentit complet, a més de ser, com la rima, un nou recurs al servei de la codificació i la memorització dels continguts que el text transmet, pot estar motivat, en part, per l'interès del rei per la literatura gnòmica, però sobretot se situa en una etapa en què Llull atorga una especial importància a les màximes, els proverbis i les proposicions com a mitjans necessaris per fonamentar els arguments que han de permetre demostrar per raons necessàries els punts més controvertits de la fe catòlica. En aquest sentit, el $D R$ es pot considerar una aplicació amb finalitats didàctiques de la capacitat de l'Art de generar aquest tipus de proposicions, ja sigui per provar directament els dogmes cristians com per establir premisses necessàries per dur a terme aquesta operació.

Cal remarcar, encara, que l'ús repetit de les proposicions condicionals, especialment en els dos primers capítols del text, és un procediment connectat amb la lògica escolàstica i que Llull importa $\mathrm{i}$ adapta de manera personal a un context didàctic $\mathrm{i}$ apologètic relacionat amb els seus interessos missioners. Uns interessos que presideixen les activitats que Llull porta a terme durant la seva estada a Mallorca al tombant de segle: la mateixa operació d'autocomentari del DR i la preparació de la versió llatina d'aquest comentari (el Tractatus), l'esforç per dinamitzar el funcionament de l'escola de Miramar, la voluntat de traduir obres com el Llibre de l'és de Déu a l'àrab, en són alguns exemples (Badia, Santanach i Soler 2012: 32-36). És per això que el DR, com a text que ha de

26 La classificació de Sari permet superar la visió estètica dels textos i té en compte tant la finalitat pragmàtica i funcional que atorga Llull a la seva obra com les principals característiques formals dels textos, però presenta problemes de discriminació en la categoria «obres de circumstància», en el sentit que no hi ha cap oposició entre la possibilitat que la redacció d'un poema hagi estat motivada per una circumstància externa i que Llull utilitzi principis o arguments de caràcter artístic per satisfer-la -i, per tant, se'n serveixi per divulgar l'Art.

27 Malgrat això, sí que és destacable l'absència de les obres en vers de caràcter més tècnic (la Lògica del Gatzell, les Regles introductòries a la pràctica de l'Art demostrativa i l'Aplicació de l'Art general) al ms. 2017 de la Biblioteca de Catalunya.

SCRIPTA, Revista internacional de literatura i cultura medieval i moderna, núm. 4 / desembre 2014 / pp. 200 - 220 ISSN: 2340-4841 $\cdot$ doi:10.7203/SCRIPTA.4.4493 
Anna Fernàndez-Clot / Francesc Tous. La persuasió de la lògica i la lògica de la persuasió: les proposicions en vers del Dictat de Ramon (1299) de Ramon Llull

persuadir el monarca català de la capacitat de Ramon per provar els articles de la fe i per aplicar aquestes demostracions en la disputa amb els infidels, pot ser interpretat com una captatio benevolentiae que ha de permetre aconseguir el suport reial perquè Llull pugui desenvolupar aquestes activitats apologètiques.

SCRIPTA, Revista internacional de literatura i cultura medieval i moderna, núm. 4 / desembre 2014 / pp. 200 - 220 ISSN: 2340-4841 $\cdot$ doi:10.7203/SCRIPTA.4.4493 
Anna Fernàndez-Clot / Francesc Tous. La persuasió de la lògica i la lògica de la persuasió: les proposicions en vers del Dictat de Ramon (1299) de Ramon Llull

\section{Bibliografia citada}

Badia, Lola (2013). «Nova retòrica i pràctica d'escriptura en Ramon Llull», Quaderns d'Italià, 18, p. 79-91.

Badia, Lola; Joan Santanach i Albert Soler (2012). «Ramon Llull, escriptor vernacle», dins Ripoll, M. / Tortella, M. (eds.) Ramon Llull i el lul lisme: pensament i llenguatge. Actes de les jornades en homenatge a J.N. Hillgarth $i$ A. Bonner. Palma/Barcelona, Universitat de les Illes Balears/Universitat de Barcelona (Col lecció Blaquerna, 10), p. 27-47.

Bonner, Anthony (2012). L'Art i la lògica de Ramon Llull. Manual d'ús. Barcelona/Palma, Universitat de Barcelona/Universitat de les Illes Balears (Col lecció Blaquerna, 9). [Trad. de l'original anglès: The Art and Logic of Ramon Llull. A User's Guide. Leiden/Boston, Brill, 2007].

Cabré, Miriam (2011). Cerverí de Girona: un trobador al servei de Pere el Gran. Barcelona/Palma, Universitat de Barcelona/Universitat de les Illes Balears (Col lecció Blaquerna, 7).

Canettieri, Paolo (2003). «Metrica e memoria», Rivista di filologia cognitiva [en línia], 1. < $\underline{\text { http:// }}$ w3.uniroma1.it/cogfil/metrica.html> [darrera consulta: 28 d'octubre de 2014].

Cifuentes Comamala, Lluís (2006). La ciència en català a l'Edat Mitjana i el Renaixement. 2a ed. ampliada. Barcelona/Palma, Universitat de Barcelona/Universitat de les Illes Balears (Col lecció Blaquerna, 3).

Domínguez, Fernando (1991). «El “Coment del Dictat” de Ramon Llull: una traducción castellana de principios del siglo XV», dins Studia in honorem prof. M. de Riquer, vol. IV, Barcelona, Quaderns Crema, p. 169-232.

Domínguez, Fernando (1996). «El "Dictat de Ramon" y el "Coment del dictat". Texto y contexto», Studia Lulliana, 36, p. 47-67.

Fernàndez Clot, Anna (2012). «Una aproximació a la Medicina de pecat de Ramon Llull», Studia Lulliana, 52, p. 25-53. [DOI: 10.3306 / STUDIALULLIANA.107.02.]

Hillgarth, Jocelyn N. (2001). Diplomatari lul lià: documents relatius a Ramon Llull $i$ a la seva família. Barcelona/Palma de Mallorca, Universitat de Barcelona/Universitat de les Illes Balears (Col lecció Blaquerna, 1).

Llull DB: Anthony Bonner (dir.), Base de dades Ramon Llull (Llull DB), Centre de Documentació Ramon Llull (Universitat de Barcelona). < $\underline{\text { http://orbita.bib.ub.edu/llull/> [darrera consulta: }}$ 28 d'octubre de 2014].

Llull, Ramon (1906-1914). Libre de contemplació en Déu. Toms I-VII, ed. Mateu Obrador, Miquel Ferrà i Salvador Galmés. Palma de Mallorca (Obres de Ramon Llull, II-VII).

Llull, Ramon (1928). Proverbis de Ramon. Mil proverbis. Proverbis d'ensenyament, ed. Salvador Galmés. Palma de Mallorca (Obres de Ramon Llull, XIV). 
Anna Fernàndez-Clot / Francesc Tous. La persuasió de la lògica i la lògica de la persuasió: les proposicions en vers del Dictat de Ramon (1299) de Ramon Llull

Llull, Ramon (1936). Rims. Tom I, ed. Salvador Galmés i Ramon d'Alòs-Moner. Palma de Mallorca (Obres de Ramon Llull, XIX).

Llull, Ramon (1938). Rims. Tom II, ed. Salvador Galmés. Palma de Mallorca (Obres de Ramon Llull, $\mathrm{XX}$.

Llull, Ramon (1958). Poesies, ed. Josep Romeu i Figueras. Barcelona, Selecta [reed. a Llull, Ramon (1988). Poesies, ed. Josep Romeu i Figueras. Barcelona, Enciclopèdica Catalana].

Llull, Ramon (1993). Raimundi Lulli Opera Latina, Tomus XIX, 86-91, Parisiis, Barcinonae et in Civitate Maioricensi annis MCCXCXIX-MCCC composita (86. Principia philosopbiae, 87-88. Dictatum Raimundi et eius Commentum, 89. Liber de orationibus, 90. Medicina peccati, 91. Compendiosus tractatus de articulis fidei catholicae), ed. Fernando Domínguez. Turnhout, Brepols (Corpus Christianorum, Continuatio Mediaevalis, CXI).

Llull, Ramon (2003). Començaments de filosofia, ed. Fernando Domínguez Reboiras; col. Eugènia Gisbert. Palma de Mallorca, Patronat Ramon Llull (Nova Edició de les Obres de Ramon Llull, $\mathrm{VI})$.

Llull, Ramon (2012). Hores de nostra dona santa Maria. Desconbort de Nostra Dona, ed. Simone Sari. Palma, Patronat Ramon Llull (Nova Edició de les Obres de Ramon Llull, XI).

Llull, Ramon (2013). Vida de mestre Ramon, ed. Anthony Bonner. Barcelona, Editorial Barcino (Biblioteca Barcino, 8).

Mensa, Jaume (2013). «Arnau de Vilanova», dins Broch, A (dir.) Història de la literatura catalana, vol. I, Badia, L. (dir.) Literatura medieval (I). Dels orígens al segle XIV. Barcelona, Enciclopèdia Catalana/ Editorial Barcino/Ajuntament de Barcelona, p. 476-509.

Morel-Fatio, Alfred (1882). «Proverbes rimés de Raimond Lulb», Romania, 11, p. 188-202.

Parramon i Blasco, Jordi (1992). Repertori mètric de la poesia catalana medieval. Barcelona, Curial.

Pere Hispà (1972). Tractatus: called afterwards summule logicales, ed. L.M. De Rijk. Assen, Van Gorcum.

Pistolsi, Elena (2009). «Tradizione e traduzione nel corpus lulliano», Studia Lulliana, 49, p. 3-50.

Platzeck, Erhard-Wolfram (1962-1964). Raimund Lull, sein Leben, seine Werke, die Grundlagen seines Denkens (Prinzipienlehre), 2 vols. Roma/Düsseldorf, Editiones Franciscanae/Verlag L. Schwann (Bibliotheca Franciscana, 5-6).

Ruffini, Mario (1966-1967). «Osservazioni sulla rima finale del "Plant de Nostra Dona Santa Maria"», Estudios Lulianos, 10, p. 129-140; 11, p. 21-30.

Ruiz Simon, Josep Maria (1999). L'Art de Ramon Llull i la teoria escolàstica de la ciència. Barcelona, Quaderns Crema (Assaig, 25).

Santini, Giovanna (2005). «Rima e memoria», Rivista di flologia cognitiva [en línia], 3. < $\underline{\text { http:// }}$ w3.uniroma1.it/cogfil/rima.html> [darrera consulta: 28 d'octubre de 2014]. 
Anna Fernàndez-Clot / Francesc Tous. La persuasió de la lògica i la lògica de la persuasió: les proposicions en vers del Dictat de Ramon (1299) de Ramon Llull

Sari, Simone (2007-2008). «Osservazioni sulla rima finale del Desconhort di Ramon Llull», Revista de Lenguas y Literaturas Catalana, Gallega y Vasca, 13, p. 233-258.

Sari, Simone (2011). «L’ufficio lulliano delle Ore», Studia Lulliana, 51, p. 53-76.

Sari, Simone (2011-2012). «740 anys de poesia lul liana. Tradició textual i noves perspectives», Mot So Razo, 10-11, p. 105-120.

Sari, Simone (2012). «Rima i memòria: estratègies mnemòniques per aprendre l'Art de Ramon Llull», dins Ripoll, M. / Tortella, M. (eds.) Ramon Llull i el lul lisme:pensament i llenguatge. Actes de les jornades en homenatge a J.N. Hillgarth $i$ A. Bonner. Palma/Barcelona, Universitat de les Illes Balears/ Universitat de Barcelona (Col leccio Blaquerna, 10), p. 375-397.

Tous, Francesc (2011). «Breus proposicions que contenen molta sentència: els proverbis lul lians i les "formes sentencioses"», Studia Lulliana, 51, p. 77-98. 